\title{
Bimbingan Dzikir dalam Meningkatkan Kecerdasan Spiritual Santri Melalui Tazkiyatun Nafs
}

\author{
Cece Jalaludin Hasan ${ }^{*}$ \\ Jurusan Bimbingan dan Konseling Islam, UIN Sunan Gunung Djati, Bandung \\ *Email : ce.jalaludin@gmail.com
}

\begin{abstract}
ABSTRAK
Tujuan penelitian ini adalah untuk mengetahui pengarahan, pengawasan dan bantuan kiyai dalam meningkatkan kecerdasan spiritual santri melalui tąkiyatun nafs di pondok pesantren At-Tamur Cileunyi Kab. Bandung. Penelitian ini dilakukan dengan metode pendekatan kualitatif deskriptif. Penelitian ini menggunakan data primer melalui observasi partisipasi moderat, wawancara semistucture (mendalam), dokumentasi yang relevan dan triangulasi (gabungan). Informan dalam penelitian ini yaitu kiyai (pembimbing), santri, ustadz dan masyarikat sekitar, dengan menggunakan teknik snowball sampling. Berdasarkan hasil analisis yang dilakukan, diperoleh kesimpulan bahwa dalam meningkatkan kecerdasan spiritual santri melalui tąkiyatun nafs dilakukan dengan pengarahan, pengawasan dan bantuan kiyai. Pengarahan kiyai yaitu upaya sebelum pelaksanaan bimbingan dzikir, pengawasan kiyai yaitu upaya selama pelaksanaan bimbingan dzikir dan bantuan kiyai yaitu upaya setelah pelaksanaan bimbingan dzikir.
\end{abstract}

Kata Kunci: Bimbingan; Dzikir; Spiritual; Tazkiyah.

\begin{abstract}
The purpose of this study is to know the direction, supervision and assistance kiyai in improving the spiritual intelligence of santri through tazkiyatun nafs at boarding school AtTamur Cileunyi Kab. Bandung. This research is done by descriptive qualitative approach method. This study uses primary data through moderate participation observation, semistucture interviews (depth), relevant documentation and triangulation (combined). Informants in this research are kiyai (supervisor), santri, ustadz, and social around, using snowball sampling technique. Based on the results of the analysis conducted, it can be concluded that in improving the spiritual intelligence of santri through tarkiyatun nafs done with guidance, supervision and kiyai assistance. The direction of the kiyai is the effort before the implementation of dhikr guidance, the supervision of kiyai is the effort during the implementation of dhiker guidance and kiyai assistance is the effort after the implementation of dhikr guidance.
\end{abstract}

Keywords: Guidance; Dhikr; Spiritual; Tarkiyah. 
C. J. Hasan

\section{PENDAHULUAN}

Pesantren lahir dari perkembangan masyarakat Islam pada masa penjajahan Belanda, sehingga sampai saat ini pesantren menjadi tempat pelengkap di suatu lingkungan masyarakat. Perkembangan masyarakat Islam tersebut sering di sebut sebagai tumbuhnya masyarakat santri. Santri merupakan murid yang belajar menuntut ilmu agama di pesantren. Ia termasuk elemen penting dalam suatu pesantren, karena dikatakan pesantren apabila memenuhi beberapa elemen yaitu pondok, masjid, pengajaran Islam, santri dan kiyai (Dhofier, 2011: 79).

Santri terdiri dari berbagai kalangan seperti anak-anak, remaja, dewasa, orang tua bahkan usia lanjut. Dalam psikologi, masa transisi dan kematangan secara sempurna (statis) yaitu terjadi pada usia dewasa dengan rentang usia antara 17-30 tahun. Pada usia ini tumbuh kematangan fisik dan motivasi untuk meraih suatu hal yang sangat besar didukung oleh kekuatan yang prima. Ditandai dengan terjadinya penyesuaian diri dengan cara gaya hidup baru dan memperoleh kebebasan dalam mengembangkan kecerdasannya, baik kecerdasan intelektual (IQ), kecerdasan emosional (EQ) maupun kecerdasan spiritual (SQ) secara matang (Hurlock, 1993: 21).

Dalam istilah namanya, saat ini pesantren di Indonesia ada yang di sebut dengan pesantren salafi (tradisional) dan pesantren modern. Pesantren salafi (tradisional) yaitu pesantren yang menggunakan sistem pengajaran kitab kuning klasik (kuno), biasanya dengan metode sorogan, bandongan, setoran hafalan, mudzakarah, muthalaah, musyawarah dan sebagainya (Dhofier, 2011: 53-54).

Sedangkan pesantren modern menurut Jeje Fauzi dalam skripsinya (2016: 2) yaitu pesantren yang menggunakan sistem pengajaran baru yang sudah mempunyai formalistic dan procedural tertentu dengan memanfaatkan teknologi modern. Sehingga dijumpai komponen-komponen pembelajaran secara formal, seperti daftar santri, buku pelajaran, media pengajaran dan terdapat juga evaluasi hasil belajar.

Beriringan dengan perkembangan zaman, pondok pesantren At-Tamur Cileunyi Kab. Bandung sudah melakukan tahapan-tahapan dalam meningkatkan pembelajaran sehingga ditemui komponen pembelajaran secara formal, seperti daftar guru dan santri, kurikulum pembelajaran, absensi kehadiran santri dan sebagainya. Namun, dalam proses pembelajarannya masih menggunakan pengajaran dengan metode sorogan, bandongan, mudzakarah, musyawarah dan setoran hafalan.

Pada dasarnya, setiap pondok pesantren mempunyai tujuan yang sama yaitu untuk menyebarkan ajaran Islam dan mengembangkan kecerdasan santri yang meliputi kecerdasan intelektual (IQ), kecerdasan emosional (EQ) dan 
kecerdasan spiritual (SQ) dengan berbagai pengajaran yang diterapkan di pesantren tersebut. Zohar dan Marshall (2001: 12-13) menyatakan bahwa kecerdasan spiritual merupakan kecerdasan tertinggi yang dimiliki oleh manusia. Kecerdasan spiritual sangat diperlukan untuk memfungsikan kecerdasan intelektual dan kecerdasan emosional secara efektif. Hal ini sependapat dengan Stephen R. Covey (2005: 79) yang menyebutkan bahwa kecerdasan spiritual merupakan pusat paling mendasar dan menjadi sumber bimbingan bagi kecerdasan lainnya.

Dengan arus kemajuan yang telah merambah ke dalam berbagai aspek kehidupan, mengharuskan individu beradaptasi terhadap berbagai perubahan yang terjadi. Sedangkan pada kenyataannya tidak semua individu mampu melakukannya, sehingga justru menyimpan banyak problematika. Kehidupan cenderung berorientasi pada materialistik, hedonistik, skolaristik dan rasionalistik dengan kemajuan IPTEK di segala bidang. Ia semakin kehilangan kendali dari visi keilahian. Keadaan ini tidak memberikan kenyamanan, tetapi justru melahirkan abad kecemasan. Kemajuan ilmu dan teknolongi yang memberikan fasilitas kemudahan, ternyata juga memberikan dampak problema psikologis bagi individu itu sendiri. Ia menjadi sangat mendewa-dewakan ilmu pengetahuan dna teknologi, sedangkan pemahaman ilmu keagamaan yang berdasakan pada wahyu ilahi sering ditinggalkan.

Tasawuf sebagai inti ajaran Islam muncul dengan memberikan solusi dan terapi bagi problematika kehidupan dengan cara mendekatkan diri kepada Allah Swt, sehingga dapat meningkatkan kecerdasan spiritual manusia. Untuk mendekatkan diri kepada Allah, ajaran Islam sangat menganjurkan untuk melakukan dzikir. Sebagaimana firman Allah Swt dalam Q.S. Al-Baqarah ayat 152 ,

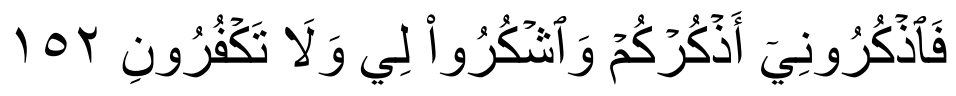

Artinya: "Karena itu, ingatlah (dzikir) kamu kepada-Ku niscaya Aku ingat (pula) kepadamu, dan bersyukurlah kepada-Ku, dan janganlah kamu mengingkari (nikmat)-Ku" (Kemenag RI: 23).

Dzikir merupakan makanan bagi jiwa manusia, jika dzikir hilang dari dirinya maka ibarat badan yang kosong dari makanannya. Dzikir juga merupakan sebuah metode yang bersumber langsung diperintahkan Allah Swt. Siapa saja orang yang banyak berdzikir kepada Allah Swt, maka Allah Swt akan jaminkan kebahagian untuknya (Aljauziyah, 2002: 64). Sebagaimana firman Allah Swt dalam Q.S. Al-Jumu'ah pada penggalan ayat 10,

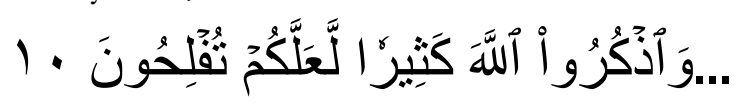

Irsyad : Jurnal Bimbingan, Penyuluhan, Konseling, dan Psikoterapi Islam 7(2) (2019) 127-148 
Artinya: “...dan berdzikirlah kamu semua kepada Allah sebanyakbanyaknya supaya kamu memperoleh kebahagiaan” (Rafi'udin, 1997: 1).

Kedua ayat tersebut merupakan ayat perintah Allah Swt kepada manusia untuk melakukan dzikir kepada-Nya. Dzikir ini merupakan amalan yang akan membuat manusia merasa bahagia dan untuk mencapai kecerdasan spiritual dalam konteks agama Islam (Subandi, 2009: 15).

Kecerdasan spiritual merupakan kecerdasan jiwa yang membantu menyembuhkan dan membangun fitrah manusia secara utuh. Kecerdasan spiritual ini bertujuan untuk menghadapi dan memecahkan persoalan makna dan nilai, yaitu menilai bahwa tindakan atau jalan hidup seseorang lebih bermakna dari pada yang lain. Ciri dari berkembangnya kecerdasan spiritual ini yaitu ditandai oleh kemampuan seseorang dalam bersikap fleksibel dan mudah menyesuaikan diri dengan lingkungan, memiliki tingkat kesadaran yang tinggi, mampu menghadapi penderitaan dan rasa sakit, mampu mengambil suatu pelajaran dari pengalamannya, mandiri dan mengerti terhadap makna hidupnya (Effendi, 2005: 4).

Pada faktanya, di pondok pesantren At-Tamur Cileunyi Kab. Bandung terdapat bimbingan dzikir (tawasulan) sebagai latihan penyucian jiwa (taqkiyatun nafs) santri, sehingga penulis memutruskan untuk melakukan penelitian di pondok pesantren tersebut. Adapun tempatnya beralamat di Jln. Cibiru Hilir No. 03-04 Rt 01 / Rw 01 Cibiru Hilir, Kecamatan Cileunyi, Kabupaten Bandung Jawa Barat 40626. Pelaksanaannya dilakukan secara rutin yaitu sekali dalam sepekan, yakni setiap kamis malam atau malam jumat setelah waktu shalat Isya. Tujuan bimbingan dzikir ini yaitu untuk meningkatkan kecerdasan spiritual santri agar mendapatkan ketenangan jiwa dan mampu berakhlak mulia dalam kehidupan sehari-hari.

Mengingat pentingnya bimbingan dzikir dalam meningkatkan kecerdasan spiritual santri melalui proses penyucian jiwa (taqkiyatun nafs). Bagaimana pengarahan, pengawasan dan bantuan kiyai dalam meningkatkan kecerdasan spiritual santri melalui tarkiyatun nafs di pondok pesantren At-Tamur Cileunyi Kab. Bandung?. Maka berdasarkan pada latar belakang tersebut, penulis tertarik untuk melakukan penelitian mengenai bimbingan dzikir dalam meningkatkan kecerdasan spiritual santri melalui tąkiyatun nafs di pondok pesantren At-Tamur Cileunyi Kab. Bandung.

Dalam penelitian terdahulu yang dilaksanakan oleh Syafrudin (2017) ditemukan bahwa semakin banyak intensitas zikir yang dilakukan dengan menggunakan metode yang benar, sesuai tuntunan Al-Qurean dan As-Sunnah, serta dalam bimbingan seorang guru mursyid, maka akan semakin banyak menghasilkan manfaat dari zikir. Jasmani dan ruhani menjadi lebih sehat, pikiran 
semakin cerdas dan jiwa menjadi tenang. Adapun penelitian yang dilakukan oleh Riyadi (2013) menyebutkan bahwa konsep zikir yang ditawarkan al-Qur'an ini dapat dijadikan sebagai salah satu metode bimbingan konseling Islam dengan mengoptimalisasi keempat fungsi bimbingan konseling Islam yaitu preventif, kuratif, preservatif, developmental atau edukatif. Selanjutnya penelitian oleh Rahman, Supriadi \& Fahrudin (2017) menyebutkan bahwa Tujuan dari pendidikan tazkiyatun nafs di Pondok Pesantren Al-huda secara umum melatih jiwa santri agar selalu dekat dengan rabbNya. Secara khusus adanya ketenangan batin yang dirasakan para santri sehingga timbul rasa di awasi oleh Allāh SWT.

Selanjutnya penelitian yang dilakukan oleh Maesaroh (2019) menunjukkan bahwa nilai intensitas dizkir ratib al-haddad yaitu 0.79 atau $79 \%$ dari setiap item pernyataan dengan kategorisasi tinggi. Sedangkan nilai kecerdasan spiritual santri sebesar 0.80 atau $80 \%$ dari setiap item pernyataan dengan kategorisasi sangat tinggi. Selanjutnya menurut Satriah (2008) bahwa pada saat ini mulai disadari bahwa pada diri manusia ada potensi lain yang turut andil dalam menentukan seluruh aktivitas dan kehidupan manusia yaitu spiritualitas

Dalam penelitian ini, penulis menggunakan jenis penelitian kulitatif deskriptif. Penelitian kualitatif deskriptif yaitu penelitian yang bertujuan untuk menggambarkan keadaan fenomena yang terjadi secara sistematik dan rasional (Hamaidi, 2008: 76). Maksudnya, penulis agar dapat menggambarkan secara sistematik dan objektif mengenai proses bimbingan dzikir dalam meningkatkan kecerdasan spiritual santri melalui tąkiyatun nafs di pondok pesantren At-Tamur Cileunyi Kab. Bandung.

\section{LANDASAN TEORITIS}

Dalam penelitian ini, sebelumnya menelaah beberapa hasil penelitian terdahulu. Pertama, Skripsi Kusmana tahun 2005 membahas tentang konsep tarkiyatun nafs yang berdasarkan pada pendekatan pemikiran tasawuf perspektif Imam AlGhazali dalam upaya meningkatkan etika seorang konselor.

Kedua, skripsi Salwa Nurul Iman tahun 2007 membahas tentang terapi dzikir yang mempunyai pengaruh dzikir terhadap kesehatan jiwa klien penggunan narkoba. Ketiga, skripsi Khoirul Mustangin pada tahun 2014 membahas tentang metode tazkiyatun nafs yang berpedoman pada pemikiran Imam Al-Ghazali mengenai shalat yang berimplikasi pada akhlak. Keempat, skripsi Muhammad Ulil Arham tahun 2015 membahas tentang dzikir sebagai terapi dengan fokus aspek spiritualnya yang berupaya memenuhi kebutuhan rasa aman, nyaman, tentram terhadap santri yang mengalami gangguan jiwa di PP. AlQodir Cangkringan Yogyakarta. 
C. J. Hasan

Dalam landasan teoritis, akan dibahas mengenai bimbingan dzikir, kecerdasan spiritual dan tazkiyatun nafs. Bimbingan dzikir terdiri dari kata bimbingan dan dzikir. Bimbingan menurut Crow adalah bantuan yang diberikan oleh seseorang, baik pria maupun wanita yang memiliki pribadi yang baik dari pendidikan yang memadai kepada seorang individu dari setiap usia untuk menolongnya mengemudikan kegiatan-kegiatan hidunya, mengembangkan arah pandangan, membuat pilihan dan memikul bebannya sendiri (Satriah, 2015: 2). Dzikir adalah membasahi lidah dengan ucapan-ucapan yang indah berupa pijian kepada Allah Swt (Nawawi, 2008: 244).

Bimbingan dzikir merupakan proses pemberian bantuan oleh seorang ahli (mursyid/kiyai) kepada individu atau kelompok dari berbagai usia secara berkesinambungan untuk mengembangkan potensi dirinya dengan cara mengingat atau mengucapkan kalimat tayibah berupa pujian kepada Allah Swt.

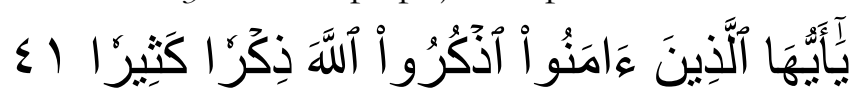

Artinya: "Hai orang-orang yang beriman, berzdikirlah (dengan menyebut nama) Allah, zikir yang sebanyak-banyaknya" (Kemenag RI, 2004: 423).

Ayat tersebut adalah perintah untuk melaksanakan dzikir dengan sebanyak-banyaknya. Mengingat Allah Swt di setiap waktu dan dalam keadaan apapun sebagai jalan untuk meraih keimanan.

Para ulama membedakan dzikir kedalam tiga macam, yaitu dzikir lisan, dzikir hati dan dzikir badan. Dzikir lisan yaitu dzikir yang dilakukan dengan dengan bersuara. Dzikir hati yaitu dzikir yang dilakukan dengan membatin, tanpa bersuara. Sedangkan dzikir badan adalah dzikir yang dilakukan dengan menundukan seluruh badan hanya kepada Allah Swt dalam rangka melaksanakan perintah dan meninggalkan larangan-Nya (Kusmana, 2009: 3).

Dzikir dapat dilaksanakan kapanpun dimanapun dan kondisi apapun. Namun, terdapat waktu tertentu yang utama untuk melaksanakannya, yaitu setelah shalat fardhu, pagi dan sore, ketika matahari tergelincir dan sepertiga malam. Adapun cara berdzikir yang disepakati ulama sufi dan syariat: (1) harus suci secara lahir atau batin, (2) khusyu dan berusaha memahami bacaan, (3) bersuara dengan sederhana, (4) menghadap kiblat, (5) menghadirkan hati dengan niat berdzikir karena Allah Swt (Soetjipto, 1986: 10).

Manfaat dzikir dalam kitab Fathul Jadid menurut Hasbiashiddiq (1994: 65) yaitu mendapatkan rahmat dan hidayah Allah Swt, membimbing hati mengingat dan menyebut asma Allah Swt, mendatangkan kebahagiaan dunia dan akhirat, memberikan cahaya pada hati dan menghilangkan kekeruhan jiwa, mendapatkan ampunan dan keridhaan Allah Swt, melepaskan perasaan was-was dan 
membentengi diri dari perbuatan maksiat (Hasbiashiddiq, 1994: 65).

Kecerdasan spiritual dalam bahasa Inggris di sebut spiritual quotient yang tersusun dari dua kata yaitu kecerdasan dan spiritual. Kecerdasan adalah kemampuan seseorang untuk memecahkan permasalahan yang dihadapinya, terutama yang menekankan pada masalah kemampuan pikiran. Spiritual adalah dasar tumbuhnya sebuah harga diri, nilai, moralitas dan rasa memiliki. Spiritual juga berarti sesuatu yang mendasar, penting dan mampu menggerakan serta memimpin cara berpikir dan tingkah laku manusia (Ginanjar, 2001: 56).

Kecerdasan spiritual merupakan kecerdasan tertinggi bagi manusia, yang dapat memfungsikan kecerdasan intelektual dan kecerdasan emosiaonal secara efektif. Kecerdasan spiritual dapat diartikan sebagai kemampuan manusia untuk menghadapi dan memecahkan masalah yang berhubungan dengan nilai, batin dan jiwa. Sedangkan Muhammad Zuhri memberikan pengertian bahwa kecerdasan spiritual adalah kecerdasan manusia yang digunakan untuk berhubungan dengan Tuhan (Zohar \& Marshall, 2001: 14).

Komponen kecerdasan spiritual menurut Davis Robert Emmons yaitu kemampuan mentransendensi, kemampuan untuk menyucikan pengalaman sehari-hari, kemampuan untuk mengalami kondisi kesadaran puncak, kemampuan untuk memecahkan berbagai masalah, dan kemampuan untuk berbuat kebajikan (Joyo, 2015).

Ciri-ciri kecerdasan spiritual yang berkembang baik ditegaskan oleh Danan Zohar dan Marshall (2001: 14) adalah (1) tawazzun / kemampuan bersikap fleksibel, (2) kaffah, artinya mencari jawaban mendasar dalam melihat berbagai masalah secara menyeluruh, (3) memiliki kesadaran tinggi serta istiqamah dalam hidup berdasarkan pada misi dan nilai, (4) tawadhu / rendah hati, (5) ikhlas dan tawakeal dalam menghadapi cobaan, (6) memiliki integritas dalam membawa visi dan nilai pada orang lain.

Menurut Covey (2001: 14) bahwa pribadi yang menjadi mandiri dan proaktif berpusat pada prinsip yang benar, digerakkan oleh nilai dan mengaplikasikan dengan integritas, sehingga dapat membangun hubungan yang baik dengan orang lain. Sehingga orang yang memiliki kecerdasan spiritual tinggi cenderung menjadi pemimpin, karena dia akan bertanggung jawab dalam membawa visi, nilai dan memberikan inspirasi terhadap orang lain (Zohar \& Marshall, 2001: 14).

Kecerdasan spiritual sangat berfungsi bagi kehidupan manusia, yaitu manusia akan menerima pada keadaan yang dihadapi sekarang, dan memberi potensi untuk berkembang, mengajarkan manusia menjadi lebih kreatif, mengatasi masalah dengan baik, mengontrol emosi dan menuntunnya pada jalan 


\section{J. Hasan}

yang benar, memberikan kemampuan beragama yang benar, membantu menyatukan antara integritas diri sendiri dan orang lain, menjadikan pribadi matang secara utuh, dan mampu menghadapi pilihan dan realitas baik atau buruk yang datang tanpa terduga (Zohar \& Marshall, 2001: 12-13).

Tazkiyatun nafs cenderung beresensi pada pembicaraan soal jiwa. Terdapat empat istilah yang terkait dengan nafs yaitu al-qalb, ar-ruh, an-nafs dan al-aql. Tazkiyatun nafs tidak hanya terbatas pada penyucian jiwa, namun juga meliputi pembinaan dan pengembangan jiwa dengan mengisinya sifat terpuji (Mustangin, 2014: 17).

Tujuan dari tazkiyatun nafs adalah tathabbur, takhallaq dan tahaqquq. Tathabbur yaitu upaya membersihkan jiwa dari mulai meninggalkan segala keburukan yang telah dilakukan di masa lampau. Takhallaq yaitu upaya menghiasi diri dengan akhlak terpuji. Dan tahaqquq yaitu upaya merealisasikan kedudukankedudukan mulia atau maqamatul qulub (Indrayani, 2016). Tarkiyatun nafs dapat dilaksanakan dengan berbagai sarana amalan perbuatan yaitu shalat, zakat dan infaq, puasa, dzikir, mengingat mati dan amar ma'ruf nabi munkar (Hawwa, 1995: 28).

Dalam penyucian jiwa terdapat dua metode yang digunakan yaitu mujahaddah dan riyadhah. Mujahaddah adalah berusaha keras dengan penuh kesungguhan hati dalam berperilaku baik. Sedangkan riyadhah merupakan suatu latihan dalam rangka membebani diri dengan membiasakan suatu perbuatan yang pada fase awal akan terasa berat dan pada fase akhir akan menjadi sebuah karakter atau kebiasaan (Nasution, 2005: 45-63).

\section{HASIL DAN PEMBAHASAN}

Penelitian ini dilakukan di pondok pesantren At-tamur atau di kenal dengan istilah pondok pesantren anak jalanan (anak adam jalan menuju Tuhan), yaitu suatu lembaga pendidikan agama Islam yang terletak di tengah-tengah masyarakat. Tepatnya berada di Jl. Cibiru Hilir No. 04 Rt/Rw 01/01 Desa Cibiru Hilir Kecamatan Cileunyi Kabupaten Bandung Jawa Barat Indonesia, kode pos 40626, Tlp./Wa: 08122158 8207, Email: attamur08@gmail.com, Facebook: Samsudin AK/Pesantren Anak Jalanan At-Tamur. Lembaga ini merupakan salah satu lembaga pendidikan Islam yang telah memenuhi syarat dan dari ketentuan kelembagaan pesantren di Indonesia berdasarkan hasil survei administrasi Kementrian Agama Republik Indonesia. Pondok pesantren AtTamur berdiri pada tanggal 20 Januari 2008 yang bertepatan dengan tanggal 10 Muharam, dengan prakarsa; (1) Samsudin, M.Ag. (2) Deden Mulyadi, M.Pdi. (3) Nisa Hermawati, M.Psi. (4) Drs. H.Ahmad Subandi. (5) Prof. Dr.H.Asep Muhyidin, M.Ag. 
Kurikulum yang terdapat di pondok pesantren At-Tamur yaitu terdiri dari beberapa materi pokok yang diajarkan; (1) pengajian Al-Quran dan Hadits, (2) pengajian kitab kuning, (3) pendidikan ibadah dan akhlak keseharian, (4) pendidikan organisasi yakni agama, budaya dan sosial kemasyarakatan, (5) kursus wirausaha khususnya Martabak dan Roti Bakar Santri. Jadwal kegiatan terbagi kedalam beberapa waktu yaitu setelah shalat maghrib hingga isya, setelah shalat isya dn setelah shalat subuh. Kabar tentang pondok pesantren At-Tamur hingga saat ini sudah meluas ke berbagai daerah di Nusantara bahkan sebagian wilayah Asia dan Amerika. Berbanding lurus dengan perkembangan kemajuan santri yang semakin bertambah baik kuantitas maupun kualitas.

Dewan guru di pondok pesantren At-Tamur yaitu orang-orang yang menjadi tenaga pengajar bagi santri, atau terkadang dari santri itu sendiri yang di anggap sudah menguasai materi ilmu tertentu secara langsung diamalkann kepada yang lainnya. Dewan guru ini yakni terdiri dari para ustadz, baik yang di minta untuk mengabdi oleh pihak pondok pesantren kepada yang bersangkutan ataupun para ustadz yang datang dengan sendirinya ingin mengabdi mengamalkan ilmunya di pondok pesantren secara sukarela (tanpa berharap gaji). Adapun santri yang terdapat di pondok pesantren At-Tamur yakni terdiri dari; (1) santri mukim yaitu santri yang tidur di pondok pesantren selama belajar berlangsung, (2) santri ngalong yaitu santri yang belajar megaji di pondok pesantren, namun tidak menginap di pemondokan, mereka pulang dan pergi ke rumah masing-masing setelah mengikuti proses pembelajaran, dan (3) santri konsultatif yaitu santri yang datang hanya untuk berkonsultasi dari berbagai macam problematika kehidupan, baik masalah agama, ekonomi, sosial, budaya, seni atau politik. Santri yang pernah mondok dan sedang mondok saat ini datang dari berbagai daerah khususnya Jawa Barat, diantaranya wilayah Bandung raya, Sukabumi, Bogor, Depok, Bekasi, Tasikmalaya, Garut, Ciamis, Majalengka, Pangandaran, Jawa Tengah, Jawa Timur dan Sulawesi.

\section{Pengarahan Kiyai}

Dalam meningkatkan kecerdasan spiritual santri tentu tidak terlepas dari pengarahan kiyai, yaitu upaya kiyai sebelum melaksanakan bimbingan dzikir. Fungsi dari kegiatan bimbingan dzikir yang dilaksanakan di pondok pesantren ini yaitu; Pertama, untuk membantu terbimbing atau santri mengingat akan perbuatan buruk (dosa) sehingga mereka menyesali dan meninggalkan semua perbuatan buruknya tersebut, dengan kata lain hal ini yang menjadi upaya dari penyucian jiwa. Kedua, memberikan motivasi pada terbimbing atau santri untuk senantiasa melakukan perbuatan baik dalam kehidupan sehari-hari. Ketiga, membantu terbimbing atau santri untuk merasakan ketenangan atau 


\section{J. Hasan}

ketentraman pada hati, pikiran dan jiwa sehingga mereka selalu ingat dan merasa dekat dengan Tuhan (Allah Swt) di setiap saat.

Adapun yang menjadi tujuan dari kegiatan bimbingan dzikir yaitu untuk membantu terbimbing atau santri membersihkan jiwanya dari mulai mengingat, menyesali dan meninggalkan perbuatan buruknya. Membantu terbimbing atau santri dengan memberikannya motivasi agar senantiasa melakukan perbuatan yang baik. Membantu terbimbing atau santri agar hati dan jiwanya merasa tenang dan dekat dengan Tuhannya. Karena dzikir mempunyai banyak keutamaan bagi kehidupan manusia. Keutamaan dzikir tersebut yaitu pertama, bahwa Allah tidak membebankan satu kewajibanpun kepada hamba-hamba-Nya melainkan Dia menetapkan batasan tertentu untuknya dan mengampuni mereka jika mereka mempunyai udzur, kecuali dzikir. Sesungguhnya Allah Swt tidak menetapkan batasan akhir untuk berdzikir dan tidak mengampuni orang yang meninggalkannya, keciali ia kehilangan akalnya. Allah Swt telah memerintahkan kepada manusia di dalam firman-Nya untuk berdzikir kepada-Nya dalam setiap keadaan.

Kedua, bahwa dzikir itu membebaskan diri dari sikap lalai dan lupa dengan menghadirkan hati secara terus menerus bersama dengan Allah Swt. Sebagian dari kalangan ulama mengatakan bahwa dzikir yaitu menyebut nama Allah dengan berulang-ulang melalui hati dan lisan. Maka dengan itu seseorang akan dapat mendekatkan diri kepada Allah Swt.

Ketiga, bahwa dzikir merupakan lembaran kekuasaan, cahaya penghubung, pencapaian kehendak, tanda awal perjalanan yang benar dan bukti akhir perjalanan menuju Allah Swt. Tidak ada sesuatu setelah dzikir, semua perangai yang terpuji merujuk pada dzikir dan bersumber daripadanya.

Keempat, tidak diragukan lagi bahwa hati itu bagaikan besi dan perak yang dapat berkarat. Dan alat yang membersihkannya yaitu dzikir. Dengan berdzikir dapat membersihkannya seperti menjadi cermin yang bersih. Apabila seseorang meninggalkan dzikir, maka hatinya akan berkarat. Dan apabila ia berdzikir, maka hatinya akan menjadi bersih. Berkaratnya hati disebabkan oleh dua perkara, yaitu lalai dan dosa. Dan yang dapat membersihkannya juga dua perkara, yaitu istighfar dan dzikir.

Kelima, bahwa keistimewaan itu terkandung di dalam ucapan, perbuatan dan benda-benda. Dan keistimewaan yang paling agung adalah keistimewaan dzikir. Karena tidak ada amal anak Adam yang paling dapat menyelamatkan dari siksa Allah Swt selain dzikir kepada-Nya. Allah Swt telah menjadikan segala sesuatu seperti obat, masing-masing mempunyai manfaat yang khusus (Sumber: Wawancara dengan Bapak Samsudin, direktur pondok pesantren, tanggal 29 Maret 2018). 
Sebelum melakukan dzikir, kiyai senantiasa mengarahkan santri melalui ngobrol perkara iman (ngopi) agar para santri termotivasi dengan hal-hal yang baik dan senantiasa melakukan kebaikan. Materi yang disampaikan adalah tentang aqidah Islam, akhlak, tasawuf atau filsafat keislaman. Pada awalnya, ngobrol perkara iman (ngopi) tersebut pertama kali dilakukan setelah peresmian pondok pesantren bersama para anak jalanan yang terdiri dari pengamen, tukang parkir, pedagang asongan dan sebagainya, dimulai dengan acara pengajian yang disepakati bersama yaitu satu kali dalam satu minggu agar tidak memberatkan mereka, yakni pada setiap sabtu malam atau malam minggu. Pelaksanaan acara pengajian tersebut sebenarnya ngobrol perkara iman dan konsultasi kehidupan sembari ngopi bareng bersama anak jalanan yang langsung di bimbing oleh pendiri pondok pesantren, bahkan menurutnya dalam awalan acara pengajian tersebut terdapat beberapa anak jalanan yang dalam keadaan sedang mabuk.

Pertama kali acara pengajian tersebut bertempat di gerasi mobil rumah Bapak H.Ahmad Subandi, yakni di belakang masjid Syarif Hidayatullah (Syahida), dari setelah melaksanakan shalat Maghrib hingga waktu shalat Isya. Kemudian acara pengajian tersebut dipindahkan tempat dan waktunya. Tempatnya dipindahkan ke masjid Syarif Hidayatullah (Syahida) lantai dua, dengan alasan karena kurang mendapatkan respon dari pemilik rumah. Dan waktunya menjadi minggu malam atau malam senin, karena pada malam minggu para pedagang asongan dan beberapa anak jalanan lainnya sibuk bekerja di jalanan.

Pada tahun 2009, acara pengajian tersebut dialihkan lagi menjadi kamis malam atau malam jumat hingga sekarang. Saat itu pengajian dilaksanakan dengan cara konsultasi atau tanya jawab seputar pembahasan tata cara beribadah yang cenderung pada pelaksanaan shalat dan berperilaku baik (menanmkan akhlak karimah). Sesuai dengan tujuan awal berdirinya pondok pesantren yaitu membina akhlak para anak jalanan yang rajin beribadah. Saat itu santri anak jalanan mencapai 70 orang, dan santri pernah diberikan tunjangan senilai Rp 500.000 ,- perorang.

Pada tahun 2010, atas bantuan dan kerjasama dengan pemerintah, pondok pesantren pernah dipindahkan ke sebuah bangunan besar dengan kontrak 1 tahun di jl. Pandanwangi Cibiru Hilir Kecamatan Cileunyi Kab. Bandung. Kemudian tahun 2011 pindah lagi ke masjid Syarif Hidayatullah (Syahida) lantai 2 , karena beberapa pembimbing dan guru tidak merasa betah dan nyaman di bangunan tersebut.

Dan pada tahun 2014, di mulai kerjasama dengan pihak Universitas Islam Negeri (UIN) Sunan Gunung Djati Bandung. Terdapat beberapa mahasiswa yang mondok di pondok pesantren dan menjadi santri di sana. Seiring dengan berjalannya waktu, acara pengajian tersebut dimasukan ke dalam kurikulum 


\section{J. Hasan}

pembelajaran pondok pesantren secara resmi yang dinamakan dengan bimbingan mudzakarah atau bimbingan dzikir, para santri sering menyebutnya dengan istilah tawasulan. Karena pada saat itu di bangun aula pondok pesantren maka kegiatan bimbingan dzikir dipindahkan dari yang biasanya dilaksanakan di dalam masjid Syarif Hidayatullah (Syahida) ke aula tersebut hingga sekarang (Sumber: Wawancara dengan Bapak Samsudin, direktur pondok pesantren, tanggal 29 Maret 2018).

Kemudian terdapat beberapa hal yang harus dipersiapkan sebelum melakukan dzikir yaitu; (1) bersih lahir batin, (2) khusyu dan paham pada bacaan dzikir, (3) bersura sederhana, yakni menyesuaikan dengan kiyai, (4) memerhatikan adab berdzikir, seperti sopan dan tawadhu, dan (5) menghadirkan hati untuk Allah Swt. Disamping itu, kiyai senantiasa mengingatkan para santri untuk memperhatikan adab sebelum berdzikir. Adab secara lahir, seseorang yanng hendak berdzikir harus suci dari pakaian, memakai wangi-wagian, berwudhu dan bersih dari segala hal yang haram. Adapun secara batin, orang yang berdzikir harus taubat agar hatinya menjadi suci, menghilangkan semua penyakit hati dari dirinya, melepaskan semua kemampuan dan kelebihannya kemudian pasrah kepada Allah Swt dengan penuh kerendahan hati.

Hal ini dijelaskan dalam buku Ahmad Soetjipto (1986: 10) bahwa persiapan dzikir tersebut sesuai dengan syariat dan ulama sufi yang telah sepakat mengenai cara-cara yang dilakukan sebelum melaksanakan dzikir agar memperoleh spiritualistas yang kuat (Soetjipto, 1986: 10).

\section{Pengawasan Kiyai}

Pengawasan kiyai merupakan upaya kiyai selama pelaksanaan bimbingan dzikir. Proses pelaksanaan bimbingan dzikir di pondok pesantren At-Tamur, penulis menganalisis kegiatan tersebut dengan mengikuti jalannya pelaksanaan dan terdapat beberapa unsur bimbingan didalamnya yaitu pembimbing (kiyai), terbimbing (santri), materi (bacaan dzikir), metode dan media.

Pembimbing dalam kegiatan ini yaitu Bapak Samsudin selaku kiyai pondok pesantren. Beliau selalu hadir untuk acara tersebut walau dalam keadaan sibuk apapun, kecuali apabila ada halangan yang sangat serius yang benar-benar tidak bisa ia tinggalkan. Hal ini ditegaskan dalam buku A. Qadir Isa (2014: 94) bahwa menurut Abdullah Ibn Abbas bahwa dzikir adalah amalan yang sangat penting dilakukan sehingga Allah tidak akan mengampuni orang yang meninggalkannya kecuali ia kehilangan akalnya. Sebagai pelaku dakwah, kiyai berkewajiban untuk mengajak orang lain agar selalu berbuat baik dan mendekatkan diri kepada Tuhan. Dalam hal ini, kiyai harus berwawasan luas dan sangat berkeinginan untuk mengembangkan jiwa spiritual santri dan mampu menanamkan akblak karimah dalam kehidupannya. Keberhasilan pelaksanaan bimbingan dzikir 
tentunya dipengaruhi oleh kepibadian santri dan tauladan yang profesional dari kiyai itu sendiri. Ia harus memiliki karakteristik yang bersifat nafsiyah, yaitu kepribadian yang sempurna secara lahir dan batin yang mencerminkan perilaku Islami. Pembimbing sebagai pelaku dakwah (kiyai) yang berkewajiban untuk mengajak orang lain agar selalu berbuat baik dan mendekatkan diri kepada Tuhan. Dalam hal ini, kiyai harus berwawasan luas dan sangat berkeinginan untuk mengembangkan jiwa spiritual santri dan mampu menanamkan akblak. karimah dalam kehidupannya. Keberhasilan pelaksanaan bimbingan dzikir tentunya dipengaruhi oleh kepibadian santri dan tauladan yang profesional dari kiyai itu sendiri. Ia harus memiliki karakteristik yang bersifat nafsiyah, yaitu kepribadian yang sempurna secara lahir dan batin yang mencerminkan perilaku Islami.

Terbimbing dalam kegiatan bimbingan dzikir ini yaitu para santri yang terdiri dari mahasiswa, masyarakat sekitar dan beberapa anak jalanan. Orang yang mengikuti bimbingan dzikir tidak dibatasi oleh usia, profesi atau pendidikan. Semua orang bisa mengikuti kegiatan ini asal mempunyai niat yang baik dan berkomitmen dengan kesungguhan hati ingin taqarub kepada Allah Swt. Jumlah jamaah yang mengikuti bimbingan dzikir ini tidak dapat dipastikan, terkadang banyak dan terkadang sedikit. Namun, secara pasti berdasarkan data yang didapatkan bahwa jumlah santri dewasa di pondok pesantren ini yaitu 27 orang. Dalam kegiatan bimbingan dzikir ini terkadang ada beberapa santri yang tidak dapat mengikutinya dengan alasan ada kegiatan lain di luar pondok pesantren yang sifatnya lebih penting (Sumber: Wawancara dengan Bapak Samsudin, pembimbing dzikir, 29 Maret 2018).

Materi yang disampaikan dalam bimbingan dzikir yaitu berupa bacaan dzikir yang sudah disusun oleh pembimbing secara berurutan. Bacaan dzikir tersebut yakni terdiri dari; (1) membaca istigfar sebanyak 100 kali, (2) membaca shalawat nabi sebanyak 33 kali, (3) membaca hauqalah sebanyak 100 kali, (4) membaca ya latif sebanyak 129 kali, (5) tawasul kepada para nabi, malaikat, sahabat, tabiin, wali dan kaum muslimin, (6) membaca lima ayat awal surat AlBaqarah, (7) membaca ayat kursi, (8) membaca dua ayat terakhir dari surat $\mathrm{Al}-$ Baqarah, (9) membaca falaq binnas, (10) membaca tasbih, tabmid, tablil dan takbir sebanyak 33 kali, (11) khusus membaca tablil sebanyak 165 kali, (12) membaca allabu allab sebanyak $13 \mathrm{kali}$, (13) membaca surat yasin berjamaah, (14) membaca doa yang dipimpin oleh kiyai, (15) membaca shalawat burdah, dan (16) membaca surat al-fatihah sebagai penutup doa.

Metode yang digunakan dalam bimbingan dzikir bermula dari riyadhah (latihan) kemudian dilanjutkan dengan mujahadah bagi santri yang sudah mencapai khusyuk. Dalam buku Nasution (2005: 47) dijelaskan bahwa metode 


\section{J. Hasan}

tarkiyatun nafs terbagi pada dua yaitu mujahadah dan riyadhah. Untuk permulaan digunakan metode riyadhah, yaitu latihan untuk melakukan suatu perbuatan tertentu (praktek) yang belum terbiasa, ini merupakan fase awal dari proses penyucian jiwa. Setelah itu, untuk pembiasaan digunakan metode mujahadah, yaitu kesungguhan dengan penuh kerja keras untuk melakukan suatu perbuatan tertentu agar menjadi terbiasa. Artinya, bimbingan dzikir ini pada awalnya hanya suatu bentuk latihan saja. Namun, apabila sudah terbiasa akan membuat santri senantiasa berbuat baik, berkata baik dan berpikir baik dalam setiap keadaan apapun.

Media artinya alat yang menghubungkan pada sesuatu. Dalam bimbingan dzikir di pondok pesantren ini media yang digunakan hanya merupakan media tatap muka dengan alat pendukung demi kelancaran kegiatan bimbingan dzikir berlangsung seperti pakaian bersih dan suci, bacaan surat Yasin, tasbe, soundtape, microphone dan hidangan makanan ringan. Pakaian bersih dan suci dikenakan oleh para santri, pembimbing dan orang-orang yang mengikuti bimbingan dzikir. Bersih dan suci agar ketika berdzikir merasakan kenyamanan dan termasuk etika ketika berdzikir. Hal ini dtegaskan dalam buku Ahmad Soetjipto (1986: 10) bahwa salah satu cara berdzikir harus dalam keadaan pantas dan suci baik lahir atau batin. Bacaan surat Yasin digunakan ketika membacakan surat Yasin berjamaah dalam kegiatan bimbingan dzikir. Adapun tasbe digunakan sebagai alat untuk menghitung jumalah dzikir yang dibaca agar sesuai dengan tuntunan dan anjuran. Soundtape dan microphone digunakan sebagai perlengkapan pengeras suara untuk pembimbing selama memimpin pelaksanaan kegiatan bimbingan dzikir. Serta hidangan makanan ringan merupakan cemilan para santri dan jamaah sebelum dzikir dimulai. Makanan tersebut datang berupa shadaqah dari warga masyarakat sekitar atau uang kas pondok pesantren atau shadaqah dari jamaah dzikir itu sendiri.

Pelaksanaan bimbingan dzikir di pondok pesantren At-Tamur Cileunyi Kab. Bandung dilaksanakan pada setiap malam jumat setelah shalat Isya. Beberapa tahapan yang dilakukan yaitu sebagai berikut.

Tabel 1

Tahap Kegiatan Bimbingan Dzikir

\begin{tabular}{lll}
\hline Persiapan & Pelaksanaan & Penutup \\
\hline $\begin{array}{l}\text { Setelah shalat Isya, jamaah } \\
\text { bersiap dan memasuki aula. }\end{array}$ & $\begin{array}{l}\text { Kiyai memberikan } \\
\text { tausiyah kepada jamaah. }\end{array}$ & $\begin{array}{l}\text { Makan bersama. } \\
\text { Konsutasi. }\end{array}$ \\
$\begin{array}{l}\text { Santri menyalami kiyai. } \\
\text { Membagikan makanan ringan. }\end{array}$ & Pelaksanaan dzikir. & \\
\hline
\end{tabular}

Sumber: Hasil wawancara penelitian, tanggal 5 April 2018. 
Berdasarkan tabel 1 bahwa bimbingan dzikir terbagi pada tiga tahap kegiatan yaitu tahap pendahuluan, pelaksanaan dan penutup. Tahap persiapan adalah setelah melaksanakan shalat Isya, kiyai, dewan guru, para santri dan jamaah lainnya bersiap untuk pergi ke aula bambu pondok pesantren, kiyai dan jamaah dzikir memasuki aula bambu, para santri menyalami kiyai dengan mencium tangannya, kemudian santri menyiapkan hidangan makanan ringan untuk dibagikan pada jamaah. Tahap pelaksanaan adalah kiyai membuka kegiatan dzikir dengan memberikan tausiyah atau ngobrol perkara Iman (ngopi) kepada jamaah dzikir, dan melangsungkan dzikir dari awal hingga akhir. Tahap penutup adalah makan bersama dengan seluruh jamaah dan setelah makan bersama jamaah dzikir dapat berkonsultasi tentang masalah kehidupan dan sebagainya kepada kiyai atau sesama jamaah lainnya sebelum bubar. Akhir dari pengawasan kiyai adalah ketika santri sudah merasakan khauf, yaitu perasaan takut kepada Allah yang ditandai dengan senantiasa beribadah secara istiqamah dalam perilakunya sehari-hari. Hal ini sebagaimana yang dijelaskan oleh Al-Ghazali bahwa aspek-aspek dalam intesitas berdzikir yang pertama adalah khauf (Sulisworo Kusdiyati, 2012: 32).

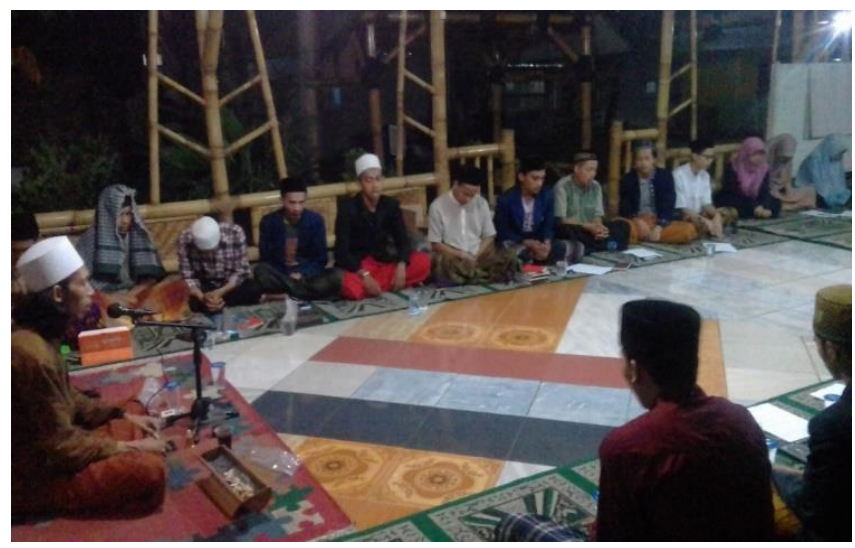

Sumber: Dokumentasi pribadi

Gambar 1. Kegiatan bimbingan dzikir

Dari gambar 1 bahwa bimbingan dzikir di pondok pesantren At-Tamur Cileunyi Kab. Bandung dilakukan secara tatap muka antara kiyai dan santri. Duduk rapih dan membentuk seperti lingkaran.

\section{Bantuan Kiyai}

Dalam meningkatkan kecerdasan spiritual santri tentu tidak terlepas dari bantuan kiyai, yaitu upaya kiyai setelah pelaksanaan bimbingan dzikir. Kecerdasan spiritual yang baik dapat terlihat dari perilaku keseharian santri yang 


\section{J. Hasan}

mencerminkan akblak karimah. Dalam konsep ilmu tasawuf, Imam Al-Ghazali menjelaskan bahwa untuk mendapatkan akblakul karimah diperoleh tahapan yang disebut tazkiyatun nafs. Berkaitan dengan bantuan kiyai dalam meningkatkan kecerdasan spiritual santri, di pondok pesantren At-Tamur dilakukan beberapa sarana tarkiyatun nafs yaitu shalat, puasa dan dzikir.

Shalat merupakan amalan yang sangat berat, karena shalat adalah wujud tertinggi dari rasa syukur seorang hamba kepada Allah Swt. Jika seseorang sudah benar dalam mengerjakannya maka selesai sudah kehidupannya, artinya kebahagiaan akan segera menjemputnya. Karena menurut makna tasawuf bahwa shalat yang sesungguhnya adalah menyatukan jiwa dengan dzat Tuhan. Sedangkan shalat yang kebanyakan dikenal oleh kita itu hanya praktek yang merupakan bentuk latihan saja, atau makna menurut ilmu fiqih (Sumber: Wawancara dengan Bapak Samsudin, tanggal 29 Maret 2018).

Berjamaah berasal dari bahasa Arab yaitu jamaah, artinya berkumpul atau banyak. Shalat berjamaah adalah shalat ( $f a r d h u)$ yang dilaksanakan secara bersama minimal oleh dua orang atau lebih yang terdiri dari imam (satu orang) dan makmum (satu orang atau lebih). Hukum mengerjakan shalat berjamaah yakni sunah muakad (pekerjaan yang lebih utama dikerjakan Nabi Saw) atau fardhu kifayah (kewajiban secara kolektif). Berlandaskan pada sabda Nabi Muhammad Saw,

"Dari Ibnu Umar ra. Rasulullah Saw bersabda, "shalat berjamaah lenih utama dari shalat sendirian dengan 27 derajat” (HR. Bukhari dan Muslim).

Dalam proses pelaksanaannya, para santri di bimbing oleh kiyai atau guru yang lainnya dalam setiap kegiatan pengajian untuk senantiasa mengamalkan shalat (fardhu) pada awal waktu secara berjamaah ketika dimana saja dia berada. Mengenai shalat berjamaah di masjid Syarif Hidayatullah (Syahida), seluruh santri diharapkan aktif berperan untuk melaksanakan shalat berjamaah dan sebagai muadzin dalam setiap waktu shalat fardhu. Imam shalat biasanya dari tokoh masyarakat sekitar atau guru-guru pondok pesantren, namun para santri juga diharapkan mampu untuk menggantikannya sebagai Imam shalat ketika mereka berhalangan shalat berjamaah di masjid Syarif Hidayatullah (Syahida). Adapun manfaat yang dapat diperoleh dari shalat berjamaah yaitu mendidik untuk berdisiplin, mendidik untuk kompak, mendidik untuk ikhlas menerima pemimpin, mendidik untuk bertanggung jawab terhadap sesama secara keseluruhan (kaffah), mendidik untuk istiqamah, sadar akan kewajiban dan tawakkal kepada Allah Swt.

Orang yang mampu shalat berjamaah adalah orang yang mempunyai jiwa yang kaya. Karena orang yang tidak mampu shalat berjamaah jiwanya tersebut masih belum cukup untuk menghadap Allah Swt. Sehingga dikatakan bahwa 
kemakmuran suatu penduduk dapat dilihat dari banyaknya penduduk tersebut yang melaksanakan shalat berjamaah (Sumber: Wawancara dengan Bapak Samsudin, direktur pondok pesantren, tanggal 29 Maret 2018).

Shalat rawatib yaitu shalat sunah yang mengiringi shalat fardhu. Waktu pelaksanaannya terbagi dua yaitu qabliyah dan ba'diyah. Qabliyah dilaksanakan sebelum shalat fardhu, sedangkan ba'diyah dilaksanakan sesudah shalat fardhu. Hukum melaksanakannya terbagi dua yaitu sunah muakkad dan ghair muakkad. Sunah muakkad yaitu sunah yang sangat dikuatkan atau dianjurkan untuk dilaksanakan karena Rasulullah Saw selalu melaksanakannya. Adapun shalat rawatib sunah muakkad meliputi; (1) dua rakaat sebelum shalat Shubuh, (2) dua rakaat sebelum shalat dzuhur, (3) dua rakaat sesudah shalat dzuhur, (4) dua rakaat sesudah shalat maghrib, dan (5) dua rakaat sesudah shalat Isya.

Sunah ghairu muakkad yaitu sunah yang dianjurkan Rasulullah Saw namun tidak selalu dilaksanakannya. Adapun shalat rawatib sunah ghairu muakkad meliputi; (1) dua rakaat sebelum dan sesudah shalat dzuhur, tambahan dari sunah muakkad, (2) empat rakaat sebelum shalat ashar, (3) dua rakaat sebelum shalat maghrib, dan (4) dua rakaat sebelum shalat Isya.

Amalan yang di hitung oleh Allah Swt menurut Bapak Samsudin bahwa bukanlah shalat fardhu melainkan shalat sunahnya seperti rawatib salah satunya. Karena shalat fardhu sudah jelas menjadi kewajiban, sedangkan shalat sunah menjadi nilai tambahan bagi seorang hamba. Shalat rawatib dikatakan juga sebagai shalat nafilah atau nawafil. Barangsiapa yang sering melakukan shalat sunah nawafil (rawatib), maka pandangannya adalah pandangan Tuhan, pendengarannya adalah pendengaran Tuhan, penciumannya adalah penciuman Tuhan, perkataannya adalah perkataan Tuhan, perasaannya adalah perasaan Tuhan bahkan gerakannya juga adalah gerakan Tuhan. Artinya bahwa jika istiqamah melaksanakan shalat sunah nawafil (rawatib), maka secara otomatis dirinya akan selalu di bimbing oleh Tuhan. Dengan arti lain disebut juga sebagai ilmu laduni yang datang langsung dari Tuhan. Segala gerakan dan aktivitasnya akan benar dan segala hal yang buruk tidak akan masuk pada dirinya karena selalu di jaga oleh Allah Swt (Wawancara 29 Maret 2018).

Puasa di pondok pesantren At-Tamur yang menjadi sarana tazkiyatun nafs sebagai bantuan kiyai dilakukan dengan puasa senin kamis, puasa mutih dan puasa ngomong. Kiyai menganjurkan bahkan mengharuskan santri untuk melaksanakan puasa sunah pada hari senin dan kamis. Puasa senin kamis ini sebagai nilai tambahan dalam meningkatkan kecerdasan spiritual bagi santri yang istiqamah mengerjakannya. Puasa mutih dianjurkan bagi santri dan siapa saja yang mempunyai hajat tertentu dan hendak datang ke pondok pesantren dengan niat karena Allah Swt. Puasa mutih ini dilakukan selama tujuh hari berturut-turut, 


\section{J. Hasan}

salah satu manfaat terbesarnya adalah akan menanamkan nilai kesabaran pada diri santri sehingga ia akan mampu menghadapi berbagai cobaan yang menimpanya. Puasa ngomong disarankan bagi santri dan siapa saja yang sedang mengalami permasalahan akibat timbul dari ucapan atau perkataan. Puasa ngomong ini dilakukan selama tiga hari secara berturut-turut siang dan malam agar menjaga lisan dari ucapan-ucapan kotor, senantiasa melatih perkataan yang membawa manfaat dan terhindar dari permusuhan.

Dzikir yang dilaksanakan di pondok pesantren At-Tamur ialah setiap malam jumat setelah shalat Isya di aula bambu pondok pesantren. Namun, selain itu, kiyai menganjurkan bahkan mengharapkan para santri dapat merealisasikan dzikir setiap saat dan dimanapun. Menurutnya bahwa dzikir yang sebenarnya adalah suatu cara atau media untuk menyebut atau mengingat nama Allah Swt. Jadi, dzikir yaitu semua aktivitas yang bertujuan untuk mendekatkan diri kepada Allah Swt, yang meliputi perbuatan baik, perkataan baik dan pikiran baik. Allah Swt berfirman, "Ingatlah kepadaku niscaya aku ingat padamu." Dampak ingat ini begitu besar, misal ingatnya seorang kekasih adalah rasa rindu, ingatnya seorang maling ingin mengambil hartamu, ingatnya dokter ingin menyembuhkanmu, ingatnya seorang bapak pada keluarganya ingin memberikan nafkah padamu. Sedangkan ingatnya Tuhan pada hamba-Nya adalah ingin memberimu rahmat, arti rahmat ini kasih sayang dan maknanya begitu luas. Jadi segala apapun yang menjadi kebutuhan kita akan Dia berikan. Syaratnya kita harus mengingat Tuhan dalam setiap keadaan dengan kalimat yang baik (thayibah). Mengingat dalam setiap keadaan bararti berdzikir di setiap saat dan dilakukan sebanyak-banyaknya, dalam keadaan berdiri kapanpun, dalam duduk kapanpun, dan dalam berbaring kapanpun. Meskipun kita dalam keadaan resah, gelisah, susah sekalipun harus tetap senantiasa berdzikir kepada Allah Swt, maka jiwa kita akan senantiasa tenang.

Dzikir adalah ketenangan sekaligus cahaya yang menghiasi hati. Dzikir akan meningkatkan kualitas takwa seorang hamba, dengan pesona takwa dari keimanannya seorang penuntut ilmu akan meraih mutiara Al-Furqan yang Allah hadiahkan untuknya. Dengan Al-Furqan tersebut bertambahlah kemampuannya untuk membedakan antara hak dan bathil, hidayah Allah kucurkan kepadanya dan menjauhlah kesesatan. Dzikir dapat direalisasikan dengan shalat dan doa. Barangsiapa yang shalat maka ia mengingat Allah Swt, assholatu lidzikri (shalatlah untuk mengingatku), dan barangsiapa yang berdoa maka ia juga sedang mengingat Allah Swt. Adapun manfaat yang akan didapatkan oleh orang yang senantiasa berdzikir kepada Allah Swt adalah: (1) dengan selalu berdzikir di setiap keadaan, akan tumbuh sikap istiqamah dalam melakukan kebaikan, tawazzun (fleksibel atau sadar di setiap keadaan) dan kaffah (berbuat baik secara menyeluruh), (2) dengan mengingat Allah Swt hati menjadi tenang, akan tumbuh 
ketenangan yang merupakan sumber keberhasilan manusia, (3) Allah Swt akan mengingat orang berdzikir, artinya Allah akan memberikan rahmat kepadanya. Maka dengan itu, akan melahirkan sikap ikhlas, raja' (penuh harap) dan tawakkal. Dengan demikian, amalan dzikir akan menimbulkan sikap-sikap dari kecerdasan spiritual dan akan besar manfaatnya dalam meningkatkan kecerdasan spiritual santri.

Hal tersebut sebagaimana yang telah dijelaskan dalam buku intisari kitab Ihya Ulumuddin tentang Konsep Tazkiyatun Nafs yang ditulis oleh Syeikh Said Hawwa, bahwa terdapat beberapa amalan ibadah yang menjadi sarana tazkiyatun nafs yaitu; (1) shalat, (2) zakat/infaq, (3) puasa, (4) dzikir/pikir, (5) mengingat kematian dan (6) amar ma'ruf nahi munkar (Hawwa, 1995: 27).

\section{PENUTUP}

Berdasarkan analisis hasil penelitian, bahwa di pondok pesantren At-Tamur Cileunyi Kab. Bandung mengenai bimbingan dzikir dalam meningkatkan kecerdasan spiritual santri melalui tarkiyatun nafs, tidak terlepas dari pengarahan, pengawasan dan bantuan kiyai dalam pelaksanaannya. Pengarahan kiyai pondok pesantren At-Tamur dalam meningkatkan kecerdasan spiritual santri merupakan upaya kiyai sebelum pelaksanaan bimbingan dzikir, yaitu dengan melakukan persiapan seperti bersih secara lahir dan batin, khusyu dan paham terhadap bacaan dzikir, bersura dengan suara sederhana (menyesuaikan dengan kiyai), memerhatikan adab berdzikir (sopan dan tawadhu), dan menghadirkan hati untuk Allah Swt.

Pengawasan kiyai pondok pesantren At-Tamur dalam meningkatkan kecerdasan spiritual santri merupakan upaya kiyai selama pelaksanaan bimbingan dzikir berlangsung. Dimulai jamaah berkumpul memasuki aula bambu tempat bimbingan dzikir, hingga jamaah berpamitan meninggalkan majelis dzikir yang menandakan kegiatan bimbingan dzikir telah selesai. Sebelum berdzikir kiyai memberikan tausiyah (ngobrol perkara Iman) kepada jamaah. Kemudian melangsungkan kegiatan bimbingan dzikir dengan bacaan yang terdiri dari tawasul, membacakan kalimat-kalimat thayibah, ayat-ayat Al-Quran, shalawat nabi dan doa bersama. Kemudian dilanjutkan dengan makan bersama dan konsultasi.

Bantuan kiyai pondok pesantren At-Tamur Cileunyi Kab. Bandung dalam meningkatkan kecerdasan spiritual santri merupakan upaya kiyai setelah pelaksanaan bimbingan dzikir, yaitu dilakukan melalui tiga sarana tąkiyatun nafs yakni shalat, puasa dan dzikir. Shalat terdiri dari; (1) shalat berjamaah dan (2) shalat sunah rawatib. Puasa terdiri dari; (1) puasa sunah senin kamis, (2) puasa mutih dan (3) puasa ngomong. Sedangkan dzikir yang dapat diwujudkan dengan perbuatan baik, perkataan baik dan pikiran baik. 
Untuk penelitian selanjutnya, diharapkan untuk dapat mengembangkan penelitian ini dengan mencari seberapa besar pengaruh bimbingan dzikir terhadap kecerdasan spiritual santri. Mengingat masih banyak hal yang perlu dikembangkan dari penelitian ini, diharapkan dapat melakukan penelitian lanjutan dengan lebih baik.

\section{DAFTAR PUSTAKA}

Al-Jauziyah, I.Q. (2002). Zikir Cahaya Kehidupan. Jakarta: Gema Insani.

Arham, M.U. (2015). Terapi Spiritual melalui Dzikir pada Santri Gangguan Jiwa di PP. Al-Qodir Cangkringan Yogyakarta. Bimbingan dan Konseling Islam, Dakwah dan Komunikasi, UIN Sunan Kalijaga Yogyakarta.

Hasbiashiddiq. (1993). Pedoman Dzikir dan Do'a. Jakarta: Bulan Bintang.

Dhofier, Z. (2015). Tradisi Pesantren. Jakarta: LP3ES.

Efendi, A. (2005). Revolusi Kecerdasan Abad I. Bandung: Alfabeta.

Fauzi, J. (2016). Tradisi Sorogan sebagai Metode Bimbingan Belajar di Pesantren. Bimbingan Konsling Islam, Dakwah dan Komunikasi, UIN Sunan Gunung Djati Bandung.

Ginanjar, A. (2001). ESQ (Emotional Spiritual Quotient). Jakarta: Arga.

Hawwa, S. 1995. Mensucikan Jiwa: Konsep Tazkiyatun Nafs Terpadu, Intisari Ihya Ulumuddin Al-Ghazali. Darussalam: Robbani Press.

Humaini. (2008). Konsep Tazkiyatun Nafs dalam Al-Quran dan Implikasinya dalam Pengembangan Pendidikan Islam. Pendidikan Agama Islam, Tarbiyah, UIN Malang.

Hurlock, E.B. (1993). Psikologi Perkembangan: Suatu pendekatan sepanjang rentang kehidupan. Jakarta: Erlangga

Isa, A.Q. (2014). Hakekat Tasawuf. Jakarta: Qisthi Press.

Joyo, I. 2015. Pentingnya ESQ dalam Manajemen Konflik bagi Perawat, di akses dari http://www.echinstitute/opini_kecerdasan_emosional_spiritual pada 20 November 2017

Kusdiyati, S. (2012). Hubungan antara Intensitas Dzikir dengan Kecerdasan Emosional dalam Ilmu Dakwah: Academic Journal, 1(12), 31-38.

Kusmana. (2005). Konsep Tazkiyatun Nafs dalam Meningkatkan Etika Seorang Konselor Islam (Studi Atas Pemikiran Tasawuf Al-Ghazali). Bimbingan dan Penyuluhan Islam, Dakwah dan Komunikasi, UIN Sunan Gunung Djati Bandung.

Maesaroh, M. (2019). Intensitas Dzikir Ratib Al-Haddad dan Kecerdasan Spiritual Santri dalam Irsyad: Jurnal Bimbingan, Penyuluban, Konseling, dan Psikoterapi Islam 7(1) 61-84.

Mustangin, K. (2014). Metode Tazkiyatun Nafs (Penyucian Diri) melalui Ibadah Shalat dan Implikasinya terhadap Pendidikan Anak. Pendidikan Agama Islam, Ilmu Tarbiyah dan Keguruan, UIN Sunan Kalijaga Yogyakarta. 
Nasution. (2005). Falsafat dan Mistisme dalam Islam. Jakarta: Bulan Bintang.

Nawawi, I. 2008. Risalah Pembersih Jiwa: Terapi Prilaku Lahir dan Batin dalam Perspektif Tasawuf. Surabaya: Karya Agung Surabaya.

Rafi'udin. (1997). Amal-amal Sorga. Jakarta: PT Raja Grafindo Persada.

Rahman, M. R. F., Supriadi, U., \& Fahrudin, F. (2017). Model Pendidikan Tazkiyatun Nafs sebagai Upaya Membentuk Akhlak Mulia Santri di Pondok Pesantren Al- Huda Kuningan Jawa Barat dalam Jurnal Pendidikan Agama Islam-Ta'lim 15(1) 37-47.

RI, Kemenag. (2004). Al-Quran dan Terjemahnya: Al-Jumanatul Ali. Bandung: CV Penerbit J-Art.

Riyadi, A. (2013). Zikir dalam al-Qur'an sebagai Terapi Psikoneurotik (Analisis terhadap Fungsi Bimbingan dan Konseling Islam) dalam KONSELING RELIGI: Jurnal Bimbingan Konseling Islam 4(1) 33-52.

Satriah, L. (2008). Pendekatan Spiritual dalam Konseling (Konseling Spiritual) dalam Irsyad: Jurnal Bimbingan, Penyuluban, Konseling, dan Psikoterapi Islam 1(1) 5-14.

Satriah, L. (2015). Bimbingan dan Konseling Kelompok. Bandung: CV Mimbar Pustaka.

Soetjipto, A. (1986). Dzikrullah. Yogyakarta: LPPM IAIN Sunan Kalijaga.

Subandi, M.A. (2009). Psikologi Dzikir. Yogyakarta: Pustaka Pelajar.

Syafrudin, S. (2017). Pendidikan Karakter melalui Aktivitas Zikir dalam Jurnal SAP 2(2) 174-180

Zohar, D. \& Marshall, I. (2001). Kecerdasan Spiritual. Bandung: Mizan. 
C. J. Hasan 